\title{
TOWARDS A TAXONOMY FOR NETWORKING MODELS FOR INNOVATION
}

\author{
Myrna Flores \\ University of Applied Sciences of Southern Switzerland (SUPSI) \\ Department of Technology and Innovation (DTI) \\ CIM Institute of Southern Switzerland (iCIMSI), SWITZERLAND \\ myrna.flores@supsi.ch
}

\begin{abstract}
In the last decades innovation has been regarded by many policy makers, economists, engineers and business managers as a key element to obtain competitive advantage. Developed countries target innovation to maintain their competitiveness and high standard of living. On the other hand, catching up countries look for innovation as a main source to alleviate poverty and provide new value added jobs and new products to the global markets. But innovation requires knowledge and continuous learning, which in many occasions for companies, specially for SME's (both in developed and catchingup countries) are difficult to achieve by themselves in a systematic way. One very important trend to enable new knowledge creation and transfer in and to SME's is the development of collaborative environments and networks to increase their innovation capabilities as a single unit but also the capabilities of the network as a whole through collective learning. As a consequence, different models have emerged from different disciplines to satisfy the need to understand, promote, enable, measure and improve the networking and learning processes among different entities to spur innovation. The objective of this paper is twofold: 1) present and classify ten identified networking models proposed by different disciplines into two main types and analyse their main strengths and weaknesses and 2) to propose a taxonomy to classify them identifying their main differences and similarities.
\end{abstract}

\section{INTRODUCTION}

A large variety of organisational forms of collaboration have emerged during the last years as a result of the many socio-economic challenges faced by the society and enabled by the new ICT developments (Camarinha and Afsarmanesh, 2004). For some authors (Camagni, 1991) creativity and continuous innovation are seen as a collective learning process, where different actors interact either in a formal or informal way for the transfer of know-how and for the imitation of successful managerial practices. As in the case of the innovation process, different disciplines have tried to analyse the collaboration and networking processes; having as a result, the emergence of different models targeting different objectives. 
Such collaboration models can be classified in mainly two groups (table 1):

Type 1: Inter and intra firm collaboration

Type 2: Networks as part of a spatial context where not only firms collaborate, but also other local agents, such as universities, research centres, associations and governmental institutions.

Table 1. Classification of Networking Models

\begin{tabular}{|c|c|}
\hline $\begin{array}{c}\text { Type 1 } \\
\text { Intra-Inter Company } \\
\text { Networking Models } \\
\text { The Firm as an individual entity or } \\
\text { part of a network (not linked to a } \\
\text { specific territory) }\end{array}$ & $\begin{array}{c}\text { Type 2 } \\
\text { National/Regional } \\
\text { Networking Models } \\
\text { Collaboration as part of a spatial } \\
\text { context, innovation for regional/national } \\
\text { competitiveness }\end{array}$ \\
\hline 1. Simultaneous Engineering & 7. Industrial Clusters \\
\hline 2. Supply Chain Management & 8. Innovative Milieu \\
\hline 3. Extended Enterprise & 9. Innovation Systems: National, \\
\hline 4. Value Chain & Regional, Metropolitan, Local \\
\hline 5. Virtual Enterprises & 10. Triple Helix \\
\hline 6. Breeding Environment & \\
\hline
\end{tabular}

\section{TYPE 1 NETWORKING MODELS: THE FIRM AS AN INDIVIDUAL ENTITY AND PART OF A NETWORK}

The first six models look forward for the networking of companies but less attention is paid to integrate local institutions (for instance Universities, Research Centres or the Government) as nodes of knowledge and technology transfer. Most of the times, these type 1 models target collaboration for innovation or operational optimisation as they have been proposed to optimise the operational processes inside the single company or the network and/or to reduce innovation costs and lead times. These models apply different Engineering methods and technologies and propose the development of new tools to reduce transactional costs and to orchestrate the innovation processes among different distributed partners in the best efficient way. The unit of analysis is "the company" of the "group of companies" that are part of the network which is formed in most occasions by partners locates in distributed locations.

One key objective proposed by these models, is the production of a new product or service from the idea to its launching into the market. Knowledge is considered as an intangible asset to be applied to develop, produce and market the innovation. Partners in the network are selected due to their competences which will be applied in terms of available skills in the new product development. Researchers in this field are usually from different Engineering schools (Manufacturing, Industrial, Mechanical and Computer Science). Business scientists and lawyers are also linked to these models, specially to understand how to obtain the best economic results of the network, define the network strategy, the business model and the legal framework. These models, contrary to the economists view "outside the black box", look for solutions that can enable better and more efficient ways of working in the network "inside the black box". Many basic and applied research projects have focused on different aspects such as: 
1) The development of Information and Communication Technologies (ICT), tools and platforms to enable the entities collaboration and information sharing

2) The analysis and design of new business models that can support the configuration and lean operation of these networks,

3) The assessment methods to select the best possible partners for the network

4) The search for new governance models

5) Readiness assessment tools to identify the readiness of partners to be part of a new or existing network

6) The legal infrastructure

7) The definition and study of the new product development and network life cycles

8) The development of roadmaps in order to enable the formation of future collaborative environments.

One important element of these models is that the innovation output targets the market or final customer needs. In other words, innovations do not remain at the inventors' backyard but target a market to serve. Engineers and business scientists realised the importance of the different functions inside the company to accomplish innovations. A multidisciplinary approach was needed to be successful in launching new products and managing daily operations. Initial networking models targeted the collaboration from different departments "inside" the organisation. Later on, with the advent of the ICT technologies and the globalisation processes both the new product development process and the overall companies' operations were interlinked with more suppliers and clients. Therefore, with time, the networking concept started to consider also suppliers and customers. The six identified type 1 models are:

Simultaneous Engineering (SE) refers to the cross-departmental/cross-company cooperation involved in engineering and marketing tasks. The specific activities are achieved individually, with the goal of parallel execution so that processes that have no dependency on other processes may be carried out at the same time. It is expected that the effectiveness of the Simultaneous Engineering within a company will impact the overall new product development lead times and costs (Ribbens J, 2002).

Supply Chain Management (SCM) is the total manage of a network of facilities and distribution options in a partnership between a consumer, distributor and manufacturer with the purpose of transfer and exchange information and physical goods for the supplier's suppliers to their customer's customers ensuring the right goods in the most efficient manner, reached accurately wherever they are required in a company and beyond (SCOR, 1995). This collaboration model looks mainly for operational processes optimisation to reduce costs and lead times. Less attention is paid to the new product development (NPD) or product innovation.

The Extended Enterprise (EE) regards a new kind of enterprise which is represented by all those organisations or parts of organisations, customers, suppliers and subcontractors and is engaged collaboratively in the design, development, production and delivery of a product to the end user (Brown, 1997). In this collaboration model, both product and process innovations are targeted. 
The idea of the Value Chain (VC) is based on the process view of organisations, the idea of seeing a manufacturing (or service) organisation as a system, made up of subsystems each with inputs, transformation processes and outputs. But the concept moved beyond the boundaries of the firm as in the real world to deliver the finished product into the market linkages with suppliers, distributors and clients within and without the same sector are required. Within value chains trust is critical to enhance inter-firm cooperation and new forms of work organisation (Porter, 1985).

The Virtual Enterprise (VE) approach is based on the ability to create temporary cooperation and to realise the value of a short business opportunity that the partners cannot (or can, but only to lesser extent) capture on their own. (Katzy \& Schuch, 1998). The purpose of the virtual enterprise is to provide a new solution for an unpredicted opportunity. Innovation is then an "intrinsic" element of this collaboration model. The concept behind the Virtual Enterprise is that it can accomplish tasks that could not be done by each of the competitors working sequentially or even in tandem, because is formed by integrating core competencies, resources and opportunities (Goldman, Nagel and Preiss, 1995).

The Breeding Environment (BE) approach emerged due to the success of several FP5 and FP6 EU funded research projects, which follow EU policies that stress the need of companies to collaborate in networks. A Breeding environment represents an association or pool of organizations and their related supporting institutions that have both the potential and the will to cooperate with each other through the establishment of a "base" long-term cooperation agreement and interoperable infrastructure Camarinha-Matos and Afsarmanesh (2004). In the BE when a business opportunity is identified by one member, a subset of these organisations can be selected and thus forming a Virtual Enterprise. One important point of this model is that its authors argue that a Breeding Environment represents a group of organisational entities that have developed a preparedness for collaboration in case a specific opportunity arises, which could be considered a "pre-condition" to form Virtual Enterprises.

In contrast with the previous type 1 collaboration models, the Breeding Environment also considers the different institutions and industrial associations as part of the breeding environment; but on the contrary, this latter does not refer to the active collaboration of partners to develop an innovative solution, rather it targets the development of a pre-condition for future collaborations to arise. It is important to mention that none of these type 1 models are related to networks linked to a territory, but on the contrary, in all of them, partners could also be located in distant locations where Information and Communication Technologies (ICT's) together with new enterprise business models will enable the collaboration and innovation (specially of SME's). One important aspect is that type 1 models look forward for the competitiveness of the single company and the partners of the network. These models are linked to the resource-based theory (Barney, 1986, 1991), where the approach to strategic management focuses on costly-to-copy attributes of the firm as sources of economic rents and, therefore, as the fundamental drivers for competitive advantage. These models do not analyse the positive or negative spillovers in the territory where partners are located. Table 2 shows the actors involved, strengths and weaknesses and the disciplines related to each one of these six type 1 models. 
Table 2. Type 1 Networking Models

\begin{tabular}{|c|c|c|c|}
\hline & $\operatorname{ACTOR}(S)$ & STRENGTHS \& WEAKNESSES & $\begin{array}{l}\text { DISCIPLI- } \\
\text { NE(S) }\end{array}$ \\
\hline $\begin{array}{l}1.1 \\
\text { SE }\end{array}$ & $\begin{array}{l}\text { - The firm } \\
\text { intends to } \\
\text { increase } \\
\text { collaboration } \\
\text { among its } \\
\text { departments } \\
\text { and also with } \\
\text { its suppliers } \\
\text { and customers } \\
\text { for the new } \\
\text { product } \\
\text { development } \\
\text { (NPD) } \\
\text { process }\end{array}$ & $\begin{array}{l}\text { STRENGTHS } \\
\text { - New product development lead time reduction } \\
\text { - Integration of the different functions inside the firm } \\
\text { enhancing information sharing } \\
\text { WEAKNESSES } \\
\text { - Doesn't consider the creation of new knowledge } \\
\text { - Doesn't study the knowledge transfer process among } \\
\text { entities, specially external } \\
\text { - Collaboration with local institutions such as } \\
\text { associations, universities and government is not } \\
\text { considered }\end{array}$ & $\begin{array}{l}\text { - Industrial } \\
\text { Engineering } \\
\text { - Mechanical } \\
\text { Engineering } \\
\text { - Manufacturing } \\
\text { Engineering } \\
\text { - Business } \\
\text { Management }\end{array}$ \\
\hline $\begin{array}{l}1.2 \\
\text { SCM }\end{array}$ & $\begin{array}{l}\text { - The firm } \\
\text { that considers } \\
\text { its suppliers } \\
\text { and customers } \\
\text { to improve its } \\
\text { operational } \\
\text { processes }\end{array}$ & $\begin{array}{l}\text { STRENGTHS } \\
\text { - Reduction of operational costs and lead times } \\
\text { - Integration of the different functions inside and outside } \\
\text { the firm enhancing information sharing } \\
\text { - Collaboration increases with the usage of new } \\
\text { Information and Communication Technologies (ICT), } \\
\text { specially Enterprise Resource Planning systems that focus } \\
\text { on sharing operational information } \\
\text { WEAKNESSES } \\
\text { - The development of new products is most of the times } \\
\text { not considered (innovation is not the main target) } \\
\text { - Collaboration with local institutions such as } \\
\text { associations, universities and government is not } \\
\text { considered }\end{array}$ & $\begin{array}{l}\text { - Business } \\
\text { Management } \\
\text { - Industrial } \\
\text { Engineering } \\
\text { - Computer } \\
\text { Science/ } \\
\text { Engineering }\end{array}$ \\
\hline $1.3 \mathrm{EE}$ & $\begin{array}{l}\text { - Mainly an } \\
\text { Original } \\
\text { Equipment } \\
\text { Manufacturer } \\
\text { (OEM) which } \\
\text { tends to } \\
\text { develop } \\
\text { closer } \\
\text { relationships } \\
\text { with clients } \\
\text { and customers } \\
\text { both for NPD } \\
\text { and to reduce } \\
\text { costs }\end{array}$ & $\begin{array}{l}\text { STRENGTHS } \\
\text { - The collaboration of partners maximises the combined } \\
\text { competencies of partners to achieve each partner's } \\
\text { strategic goals and to provide solutions to meet customers } \\
\text { needs } \\
\text { - Collaboration increases with the usage of new } \\
\text { Information and Communication Technologies (ICT), } \\
\text { specially Enterprise Resource Planning softwares (ERPs) } \\
\text { WEAKNESSES } \\
\text { - Usually the OEM orchestrates the New Product } \\
\text { Development (NPD) process, SME's have very little } \\
\text { decisional power } \\
\text { - Collaboration with local institutions such as } \\
\text { associations, universities and government is not } \\
\text { considered }\end{array}$ & $\begin{array}{l}\text { - Industrial } \\
\text { Engineering } \\
\text { - Mechanical } \\
\text { Engineering } \\
\text { - Manufacturing } \\
\text { Engineering } \\
\text { - Computer } \\
\text { Engineering } \\
\text { - Business } \\
\text { Management }\end{array}$ \\
\hline $\begin{array}{l}1.4 \\
\text { VC }\end{array}$ & $\begin{array}{l}\text { - Mainly } \\
\text { companies } \\
\text { considering } \\
\text { suppliers and } \\
\text { customers in } \\
\text { the networks }\end{array}$ & $\begin{array}{l}\text { STRENGTHS } \\
\text { - The idea of seeing a manufacturing (or service) } \\
\text { organisation as a system, made up of subsystems each } \\
\text { with inputs, transformation processes and outputs. } \\
\text { - Divides internal business as primary and secondary to } \\
\text { concentrate on activities that add value } \\
\text { - The initial concept moved beyond the boundaries of the } \\
\text { firm as in the real world to deliver the finished product }\end{array}$ & $\begin{array}{l}\text { - Business } \\
\text { Management } \\
\text { and Strategy } \\
\text { - Development } \\
\text { Studies }\end{array}$ \\
\hline
\end{tabular}




\begin{tabular}{|c|c|c|c|}
\hline & & $\begin{array}{l}\text { into the market linkages with suppliers, distributors and } \\
\text { clients within and without the same sector are required. } \\
\text { - By some researchers in development studies, the } \\
\text { formation and growth of clusters can be a possibility for } \\
\text { developing countries to compete in global markets } \\
\text { WEAKNESSES } \\
\text { Many times analysis are realised by economists looking } \\
\text { only at the "outside the box" results. The model doesn't: } \\
\text { - Analyse deeply the new product development process } \\
\text { - Focus to improve the collaboration process among } \\
\text { partners with new technologies, procedures and tools. }\end{array}$ & \\
\hline $\begin{array}{l}1.5 \\
\mathrm{VE}\end{array}$ & $\begin{array}{l}\text { - Mainly } \\
\text { companies } \\
\text { - Special } \\
\text { attention to } \\
\text { develop and } \\
\text { integrate core } \\
\text { competences } \\
\text { of Small and } \\
\text { Medium Size } \\
\text { companies in } \\
\text { the temporal } \\
\text { alliance } \\
\text { (SME's) }\end{array}$ & $\begin{array}{l}\text { STRENGTHS } \\
\text { - Partners of the VE should be able to share their core- } \\
\text { competences (technology, business process or resources) } \\
\text { to develop a new product or service with non- } \\
\text { reproducible characteristics in the market. } \\
\text { - The network has a short life, because it usually satisfies } \\
\text { a specific need, usually an specific project is realised, and } \\
\text { then the Virtual Enterprise dissolves } \\
\text { - Partners in a Virtual Enterprise model can be } \\
\text { geographically distributed and the model provides a way } \\
\text { for SME's to collaborate in global networks. } \\
\text { WEAKNESSES } \\
\text { - Depends strongly on the availability of Information and } \\
\text { Communication Technologies. If a company doesn't } \\
\text { count with ICT is very difficult for it to join a VE } \\
\text { - The set-up of the network for a temporal alliance is not } \\
\text { an easy task. General speaking a business opportunity } \\
\text { should be first identiffed and an external entity mainly } \\
\text { called "a broker" that will also orchestrate the new VE. } \\
\text { - National and/or regional policies that enable or reduce } \\
\text { the imnovation capabilities of companies are not } \\
\text { considered in the analysis }\end{array}$ & $\begin{array}{l}\text { - Computer } \\
\text { Engineering } \\
\text { - Manufacturing } \\
\text { Engineering } \\
\text { - Mechanical } \\
\text { Engineering } \\
\text { - Inđustrial } \\
\text { Engineering } \\
\text { - Business } \\
\text { Management } \\
\text { - Law Schools }\end{array}$ \\
\hline $\begin{array}{l}1.6 \\
\text { BE }\end{array}$ & $\begin{array}{l}\text { - Companies } \\
\text { and their } \\
\text { related } \\
\text { supporting } \\
\text { institutions } \\
\text { (such as } \\
\text { associations) }\end{array}$ & $\begin{array}{l}\text { STRENGTHS } \\
\text { - The approach proposes a network of organisations that } \\
\text { are "prepared" to collaborate. Once a new business } \\
\text { opportunity is identified a new Virtual Enterprise will be } \\
\text { formed. } \\
\text { WEAKNESSES } \\
\text { - The breeding environment (BE) will need a strong } \\
\text { leadership and a common objective to hold together the } \\
\text { members which will be ready to collaborate. If these } \\
\text { elements don't exist, the BE will hardly show results. } \\
\text { - As members of the BE are not all located in the same } \\
\text { territory/region they will depend strongly on the ability of } \\
\text { a Information and Communication Technologies (ICT) to } \\
\text { enable this network approach to hold on together while } \\
\text { the business opportunity appears or is identified by the } \\
\text { broker. } \\
\text { - New models are needed to incorporate Universities in } \\
\text { the Virtual Enterprises to be formed out of the BE. } \\
\text { - National and/or regional policies that enable or reduce } \\
\text { the innovation capabilities of companies are not } \\
\text { considered in the analysis. }\end{array}$ & $\begin{array}{l}\text { - Industrial } \\
\text { Engineering } \\
\text { - Mechanical } \\
\text { Engineering } \\
\text { - Manufacturing } \\
\text { Engineering } \\
\text { - Computer } \\
\text { Engineering } \\
\text { - Business } \\
\text { Management } \\
\text { - Law Schools }\end{array}$ \\
\hline
\end{tabular}




\section{TYPE 2 NETWORK MODELS: COLLABORATION AS PART OF A SPATIAL CONTEXT FOR REGIONAL / NATIONAL DEVELOPMENT}

On the other hand, type 2 models have developed and applied mainly by Economists, Sociologists and Policy Makers to understand how the collaboration and collective learning processes impact and increase the innovation capabilities of regions and nations and to identify and define the different policies that could be implemented to increase competitiveness. These models do not usually focus on the interaction processes or technologies used among individual firms or the single network or how to improve their operation, but on the aggregation mechanisms of companies located in a specific location and the macro innovation outputs such the region/nation per capita income, number of new high tech companies or the number of new patents. The infrastructure provided to these networks to collaborate and innovate in terms of policies, tax incentives, available and skilled workforce, venture capital, university laboratories and public/private R\&D are some of the input variables usually analysed to understand why some regions/nations are more innovative than others.

In these type 2 models, regional and national economic performance depends upon the progressive introduction over time of innovations in products and processes to enhance the competitiveness of the regional and national economic base in an increasingly competitive world. Mainly, these models have emerged to analyse the importance and impact of the different actors, the knowledge and learning collective processes and policies that are present at the national, regional, local and metropolitan levels that support innovation in a spatial context. Special attention is paid to the interaction and collective learning of the different agents in the territory such as Firms, Universities and Governments. In this case, the unit of analysis is the "network(s) of entities inside a specific location or territory".

In contrast with the type 1 collaboration models where both basic and applied research are performed to improve the efficiency of the firm or network by providing new tools and methods (typical of an engineering perspective), type 2 models are studied under an economist perspective, in other words the innovation process is not studied inside the "black box". Economics has traditionally primarily dealt with the allocation of resources to innovation (in competition with other ends) and its economic effects, while the innovation process itself has been more or less treated as a "black box". What happens within this "box" has been left to scholars from other disciplines (Fagerberg, 2003).

The first type 2 collaboration model is the Industrial Cluster (IC). It is defined as a concentration of 'interdependent' firms within the same or adjacent industrial sectors in a small geographical area (Observatory of European SMEs, 2002). Porter (1990) defines a cluster as a set of industries related through buyer-supplier and supplier-buyer relationships, or by common technologies, common buyers or distribution channels, or common labour pools. In the last years, there has been an explosion of interest in cluster development across North America, Europe and newly industrialized countries. This interest has been prompted, in part, by fascination with the success of Silicon Valley at reinventing itself through successive waves of new technology; and, in part, by the efforts of other regions to 
emulate the Silicon Valley model. Saxenian's case study of Silicon Valley undertaken in the early 1990 s and the comparison she provided with Route 128 in Massachusetts was one of the initial case studies analysing Silicon Valley success (Wolfe, 2003).

The second model within the type 2 is the Innovative Milieu (IM). It is based on the hypothesis (Aydalot, 1986) that "Local environments play a determinant role as innovation incubators, they act like a prism through which innovations are catalysed and which give the area its particular complexion. A firm is not an isolated innovator, it is part of an area which makes it act and react. The history of an area, it's organisation, it's collective behaviour and it's internal structure of unanimity are the principal components of innovation". This hypothesis justifies an analysis which goes beyond the permissive conditions which enhance the creation and establishment in a particular locality of innovative firm. According to the GREMI (Group de Recherche Européen sur les Milieux Innovateurs) an innovative milieu is the set of relationships that occur within a given geographical area that bring unity to a production system, economic actors, and an industrial culture, that generate a localised dynamic process of collective learning and that act as an uncertaintyreducing mechanism in the innovation process (Camagni, 1995). Many of the studies developed under the innovative milieu approach analyse the learning process for innovation; in fact, the GREMI Group argues that a territory with weak interactions and no learning can't be considered an innovative milieu.

On the other hand, the Innovation Systems (IS) model takes into consideration the network of institutions in the public and private sectors, whose activities and interactions initiate, import, modify and diffuse new technologies (Freeman, 1987). This approach considers that the elements and relationships which interact in the production, diffusion and use of new and economically useful knowledge are either located within or rooted inside the boarders of a nation or region. The characteristics of an innovation system can be summarized as (Lundvall, 1992):

- Firms are part of a network of public and private sector institutions whose activities and interactions initiate, import, modify and diffuse new technologies

- An IS consists of linkages (both formal and informal) between institutions

- An IS includes flows of intellectual resources between institutions

- Analysis of IS emphasizes learning as a key economic resource and that geography and location still matter.

The fourth and last type 2 identified model is the Triple Helix (TH). It has been proposed by Henry Etzkowitz and Loet Leydesdorff (2000) and states that Universities play an enhanced role in innovation in increasingly knowledge-based societies. This approach proposes a new level of interaction: University-IndustryGovernment promoting a "third revolution" in the academic system, where Universities will target a "third mission" of economic development in addition to research and teaching; "The heart of the Triple Helix thesis is an expansion of the role of knowledge in society and of the university in the economy". The Triple Helix Model opens up a new perspective; universities can benefit economically from their innovations, by creating "spin-offs", selling their patents to industry offering consulting services by transferring technology to local companies enabling a sustainable economic development of their regions. 
Table 3. Type 2 Networking Approaches

\begin{tabular}{|c|c|c|c|}
\hline & ACTOR(S) & STRENGTHS \& WEAKNESSES & $\begin{array}{l}\text { DISCIPLI- } \\
\text { NE(S) }\end{array}$ \\
\hline $\begin{array}{l}2.1 \\
\text { IC }\end{array}$ & $\begin{array}{l}\text { - Companies } \\
\text { localised in a } \\
\text { specific region } \\
\text { - Strong } \\
\text { emphasis on } \\
\text { SME's }\end{array}$ & $\begin{array}{l}\text { STRENGTHS } \\
\text { - Proximity facilitates the transfer of knowledge an } \\
\text { information } \\
\text { - A skilled pool of workers facilitates innovation } \\
\text { - Universities such as Stanford in Silicon Valley and } \\
\text { Cambridge in Cambridge have played a key role by } \\
\text { transferring knowledge and by increasing the innovate } \\
\text { capabilities generating hi-tech clusters } \\
\text { WEAKNESSES } \\
\text { - Clusters have also been approached by their capacity to } \\
\text { generate knowledge and their learning capabilities, } \\
\text { nevertheless in a cluster not all companies collaborate and } \\
\text { share information } \\
\text { - There is not a unique strategy to develop clusters and } \\
\text { make them successful as each country and region relies on } \\
\text { different cultures and policies. }\end{array}$ & $\begin{array}{ll}\text { - } & \text { Business } \\
& \text { Management } \\
\text { - Economists } \\
\text { - Sociologists } \\
\text { - Political } \\
\text { - Science }\end{array}$ \\
\hline $\begin{array}{l}2.2 \\
\mathrm{IM}\end{array}$ & $\begin{array}{l}\text { - Enterprises, } \\
\text { regional socio- } \\
\text { professional } \\
\text { associations, } \\
\text { local and } \\
\text { regional } \\
\text { authorities, } \\
\text { universities and } \\
\text { laboratories, } \\
\text { schools and } \\
\text { individuals. }\end{array}$ & $\begin{array}{l}\text { STRENGTHS } \\
\text { - Proximity facilitates the transfer of knowledge an } \\
\text { information } \\
\text { - Focuses on the collective learning process to enable } \\
\text { innovation } \\
\text { WEAKNESSES } \\
\text { - This approach doesn't study the learning process at the } \\
\text { company level but in a "macro" regional perspective which } \\
\text { is not easy to measure and replicate } \\
\text { - It doesn't take into consideration the possible technologies } \\
\text { that can facilitate the collective learning process }\end{array}$ & $\begin{array}{l}\text { Regional } \\
\text { Economists }\end{array}$ \\
\hline $\begin{array}{l}2.3 \\
\text { IS }\end{array}$ & $\begin{array}{ll}\text { - } & \text { Companies } \\
\text { - } & \text { Institutes } \\
\text { - Universities } \\
\text { - } & \text { Government }\end{array}$ & $\begin{array}{l}\text { STRENGTHS } \\
\text { - Takes into consideration the policies that can enable or } \\
\text { hinder collaboration at national and regional levels. } \\
\text { - The knowledge transfer process among companies and } \\
\text { universities is analysed } \\
\text { - Considers different units of analysis: national, regional, } \\
\text { metropolitan and local. } \\
\text { - The MIT developed the Local Innovation Systems (LIS) } \\
\text { where successful locations are studied } \\
\text { WEAKNESSES } \\
\text { - In most cases, the analysis of the innovation process is } \\
\text { performed "out of the box" under an economist perspective. } \\
\text { - Non-successful case studies of new products developed } \\
\text { under this model are rarely described }\end{array}$ & $\begin{array}{ll}\text { - } & \text { Business } \\
& \text { Management } \\
\text { - } & \text { Economists } \\
\text { - } & \text { Sociologists } \\
\text { - } & \text { Development } \\
& \text { Studies } \\
\text { - } & \text { Policy } \\
& \text { Studies }\end{array}$ \\
\hline $\begin{array}{l}2.4 \\
\text { TH }\end{array}$ & $\begin{array}{ll} & \text { Companies } \\
\text { - } & \text { Research } \\
& \text { Institutes } \\
\text { - } & \text { Universities } \\
\text { - } & \text { Government }\end{array}$ & $\begin{array}{l}\text { STRENGTHS } \\
\text { - The entrepreneurial university takes a proactive stance } \\
\text { in putting knowledge to use and in broadening the input } \\
\text { into the creation of academic knowledge. } \\
\text { WEAKNESSES } \\
\text { - Non-successful case studies of new products developed } \\
\text { under this approach are rarely described } \\
\text { The collaboration between Universities and Local } \\
\text { industries is rarely studied in detail by researchers }\end{array}$ & $\begin{array}{ll}\text { - } & \text { Policy } \\
& \text { Studies } \\
\text { - } & \text { Sociologists } \\
\text { - } & \text { Economists }\end{array}$ \\
\hline
\end{tabular}




\section{A PROPOSED TAXONOMY TO ANALYSE NETWORKING MODELS}

As observed, each networking model targets different objectives and goals, therefore is not an easy task to classify them and analyse their similarities and main differences. In order to realise this comparison a taxonomy has been developed. The proposed taxonomy analyses each model under four major areas: 1) Geography, 2) Collaborating Entities, 3) Scope and 4) Collaboration Enabling Factors. For each identified element under the previous four major areas of the proposed taxonomy a value of " 0 " (not considered), "1" (low), "2" (medium) or "3" (high) was given taking into consideration its importance for each specific networking model (Table 5). Table 4 shows which are the most important elements for type 1 and type 2 under the four taxonomy elements.

Table 4. Type 1 and Type 2 key elements

\begin{tabular}{|c|c|c|}
\hline & \multicolumn{2}{|c|}{ TYPES OF NETWORKING MODELS } \\
\hline $\begin{array}{l}\text { TAXONOMY } \\
\text { ELEMENTS }\end{array}$ & $\begin{array}{c}\text { Type } 1 \\
\text { Intra-Inter Company }\end{array}$ & $\begin{array}{c}\text { Type } 2 \\
\text { National/Regional }\end{array}$ \\
\hline 1 Geography & $\begin{array}{l}\text { Intra-Inter Company } \\
\text { Networks not linked to a } \\
\text { territory, partners are } \\
\text { geographically distributed }\end{array}$ & $\begin{array}{l}\text { National or Regional Territorial } \\
\text { Networks }\end{array}$ \\
\hline $\begin{array}{l}2 \\
\text { Collaborating } \\
\text { Entities }\end{array}$ & $\begin{array}{l}\text { Departments' functional } \\
\text { collaboration inside the } \\
\text { company } \\
\text { Network of Companies } \\
\text { (usually in distributed } \\
\text { locations) }\end{array}$ & $\begin{array}{ll}\text { Network of local/national: } \\
\text { - } & \text { Companies } \\
\text { - } & \text { Companies and Associations } \\
\text { - Companies and Universities Universities and } \\
\text { Government } \\
\end{array}$ \\
\hline 3 Scope & $\begin{array}{l}\text { Operational Costs and } \\
\text { Transaction Costs Reduction } \\
\text { New Product Development } \\
\text { and Innovation }\end{array}$ & $\begin{array}{l}\text { - New Product Development and } \\
\text { Innovation for regional/national } \\
\text { competitiveness } \\
\text { - Collective Learning } \\
\text { - } \quad \text { Knowledge Transfer } \\
\text { Sustainable National/Regional } \\
\text { - } \quad \text { Newomic Development } \\
\text { definition }\end{array}$ \\
\hline $\begin{array}{l}4 \\
\text { Collaboration } \\
\text { Enabling } \\
\text { Factors }\end{array}$ & $\begin{array}{ll}\text { - Information and } \\
\text { Communication Technologies } \\
\text { (ICT) } \\
\text { Reduction of costs and lead } \\
\text { times as a main goal } \\
\text { - Common goal to develop new } \\
\text { product(s) } \\
\text { Trust }\end{array}$ & $\begin{array}{ll}\text { - } & \text { Proximity } \\
& \text { Development and sharing of } \\
\text { - } & \text { New Know Capital } \\
\text { - National/Regional culture for } \\
\text { Innovation and Collaboration } \\
\text { - Governmental Policies } \\
\text { - Trust }\end{array}$ \\
\hline
\end{tabular}


Table 5. Analysis of Networking Approaches using the proposed Taxonomy

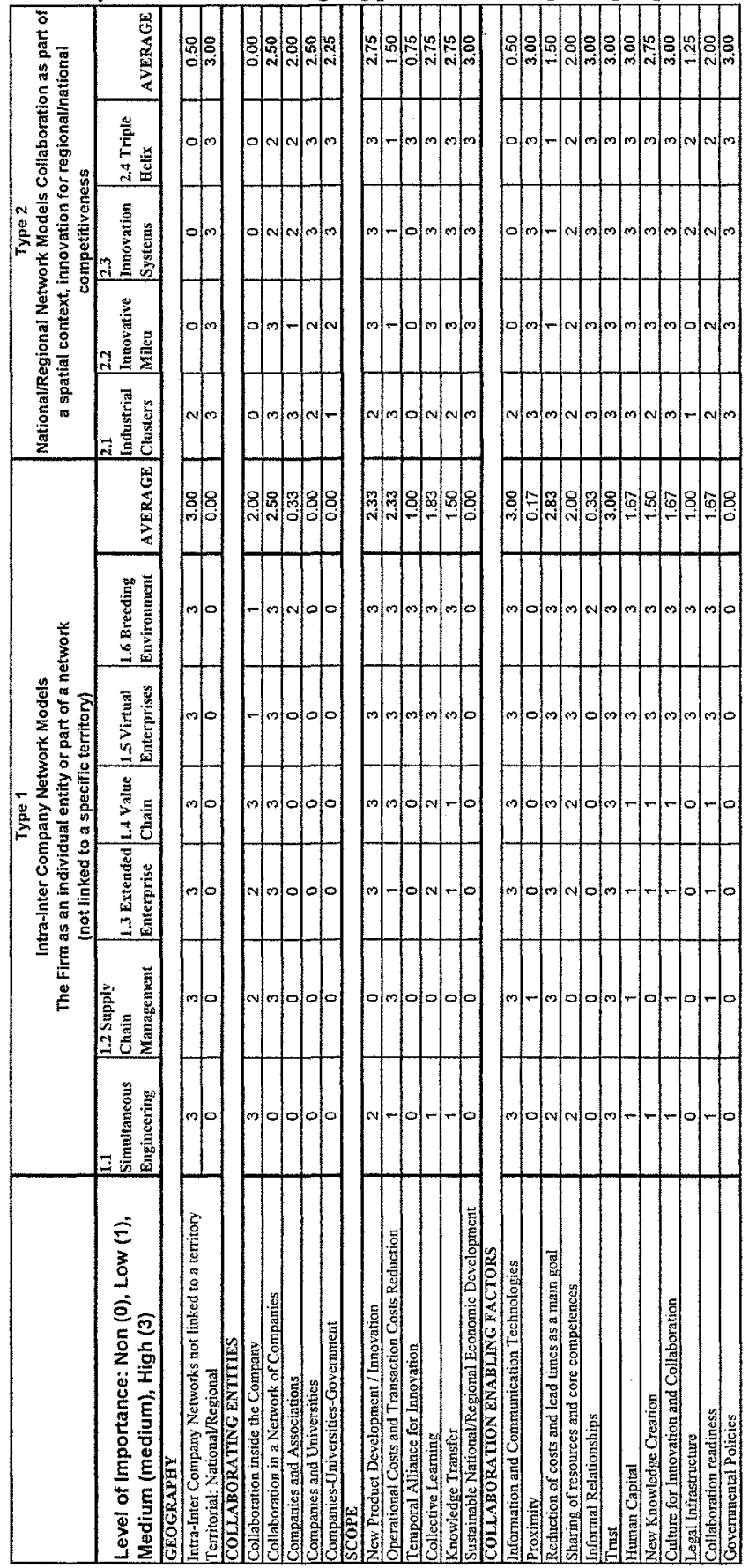




\section{CONCLUSIONS}

Several disciplines are targeting in one way or the other to study the networking process of different entities to carry out innovations proposing different models to understand their interactions. As observed, there is not a unique model to cover all the needs and angles. This paper proposed a classification of ten different networking models into Type 1) firm-global network oriented and Type 2) local, regional, national network oriented. A taxonomy has been presented to analyse their main differences and similarities taking into consideration four main elements: 1) Geography, 2) Collaborating Entities, 3)Scope and 4) Collaboration Enabling Factors. The most amazing learning lesson during this research was that even if the different disciplines work in parallel in the same topic, there is very little interaction among them to share concepts and ideas that could enable to cover the different needs in a engineering oriented, economical, political and social perspective; additionally, a common ontology is required to have a common set of definitions.

\section{REFERENCES}

1. Afsarmanesh H, Camarinha-Matos L., A Framework for Management of VO Breeding Environments, In Collaborative Networks and Their Breeding Environments Eds. Camarinha-Matos, Luis M.; Afsarmanesh, Hamideh; Ortiz, Angel, Springer 2005.

2. Aydalot P., "Milieux innovateurs en Europe", Paris, GREMI, C3E, 1986

3. Barney, J., "Strategic factor markets: expectations, luck, and business strategy", Management Science, 1986, Vol. 32, No. 10, 1231-1241.

4. Barney, J., "Firm Resources and Sustained Competitive Advantage", Journal of Management, 1991, Vol. 17, No. 1, 99-120.

5. Browne J., I. Hunt and J.Zhang, The Extended Enterprise, Handbook of Life Cycle Engineering: Concepts, Models and Technologies, edited by Molina, Sanchez \& Kusiak, Kluwer, 1998,

6. Camagni R, Innovation Networks, The GREMI Approach, British Library Cataloguing in Publication Data, 1991

7. Camarinha-Matos L. and Afsarmanesh H., Collaborative Networked Organizations, A research agenda for emerging business models, 2004

8. Etzkowitz H. Leydesdorff L. The dynamics of innovation: from National Systems and "Mode 2" to a Triple Helix of university-industry-government relations, Research Policy 29, 2000 109-123.

9. Fagerberg 3., Innovation: A Guide to the Literature, Paper presented at the Workshop "The Many Guises of Innovation: What we have learnt and where we are heading", Ottawa, October 23-24.2003, organized by Statistics Canada.

10. Freeman, C., Technology Policy and Economic Performance: Lessons from Japan. Pinter, London.

11. Goldman, Nagel and Preiss, 1995, Agile Competitors and Virtual Organisations-Strategies for enriching the customer, Van Nostrand Reinhold, 1987.

12. Katzy B., and Schuh, The Virtual Enterprise, Handbook of Life Cycle Engineering: Concepts, Models and Technologies, edited by Molina, Sanchez \& Kisiak, 1998.

13. Lundvall B.A., Natinal Systems of Innovation, Towards a Theory of Innovation and Interactive Learning, 1992

14. Observatory of European SMEs, Regional clusters in Europe, European Community, http://europa.eu.int/comm/enterprise, (2002)

15. Porter, M. Competitive advantage: Creating and sustaining superior performance. New York: The Free Press, 1985

16. Porter M., The Competitive Advantage of Nations. Free Press, New York, 1990.

17. Ribbens J., Simultaneous Engineering for New Product Development: Manufacturing Applications, Wiley, 2000

18. SCOR, Suppy Chain Operations Reference Model, www supply-chain.org 1995

19. Wolf D.A. Clusters from the Inside and Out: Lessons from the Canadian Study of Cluster Development, Paper to be presented at the DRUID Summer Conference 2003 on Creating, Sharing and Transferring Knowledge, the role of Geography, Institutions and Organizations, 2003. 